\title{
Edukacja olimpijska szansą na zmniejszenie zjawiska wypadania dzieci i młodzieży z systemu oświaty
}

\author{
Abstract \\ Olympic Education as a chance of reducing the phenomenon \\ of youngsters dropping out from educational system
}

The work includes analysis of the basis of the Olympic Education Concept and its use in prevention of school dropout. Olympic Education is supported by the values of modern Olympic and sport. Its theoretical grounds constitute sport pedagogy developed by Baron Pierre de Coubertin. Coubertin did not create any particular educational system and didn't introduce any definition of sport pedagogy. The lack of the rigid concept can be considered as a quality. It enables us to use the olympism and its rules to solve many problems of continuously developing World, which emerge from the needs of new generations and challenges they face. New methodological conceptions based on Olympic values have been created for decades. It is expected that the conceptions can bring many benefits for individuals and social groups. New programs have been developed, their implementation area has been broadened in order to form proper social attitudes as well as amending various pathological phenomenon. There is a strong premise to introduce the Olympic values to school system in order to boost the efficiency of educational work mainly to achieve better pupils motivation for learning and to strengthen integration of the school environment.

Olimpizm jest filozofią życia, wyrażającą i łączącą w wyważoną całość wartości ciała, woli i umysłu łącząc sport z kulturą i wychowaniem, olimpizm dąży do stworzenia drogi życia opartej na radości znajdowanej w wysiłku, wychowawczej wartości dobrego przykładu i na szacunku wobec uniwersalnych i fundamentalnych zasad etycznych. 


\section{Edukacja olimpijska}

Dzieło Pierre'a de Coubertin, które wsparte zostało na wartościach wielu kultur oraz dokonań wybitnych myślicieli i aktywistów, jest kontynuowane do dziś i obejmuje dwa cele. Pierwszym z nich jest wskrzeszenie igrzysk olimpijskich, co zostało w pełni zrealizowane, przerastając najśmielsze oczekiwania nawet największych optymistów. Drugi to cel pedagogiczny - o wiele bardziej wymagający - i polega on na wykorzystaniu olimpizmu jako praktycznej szkoły moralnego, intelektualnego i fizycznego doskonalenia człowieka. Stworzona przez de Coubertina oraz jego współpracowników i kontynuatorów doktryna ma holistyczny charakter. Obejmuje edukację sportową, edukację dla pokoju, edukację społeczną, kulturę i sztukę, wychowanie do higieny oraz kształtowanie charakteru w duchu rycerskim (Płoszaj 2014).

W zamyśle P. Coubertina jego pedagogiczna koncepcja miała przede wszystkim służyć pokojowemu współistnieniu wszystkich obywateli świata. Zrealizowanie tego szczytnego zamierzenia polega na zbliżeniu ludzi do siebie, umożliwieniu im wzajemnego poznania się oraz tolerancji i szacunku. Bardzo dużą rolę w osiągnięciu tych celów ma zrozumienie drugiego człowieka. W przekonaniu Coubertina najlepiej mogła się do tego przyczynić wspólnie podejmowana i wspólnie organizowana aktywność sportowa.

Pierre de Coubertin postrzegał sport jako ważną składową rzeczywistości społeczno-kulturowej. Uznawał go za istotny czynnik w procesie rozwoju i wychowania człowieka, będący nieodzowną cząstką jego życia. Sport jako inspiracja do wszelkiej aktywności i motywacja do bycia lepszym. Sport jako źródło radości i silnych emocjonalnych przeżyć. Sport jako płaszczyzna przyjaznych i życzliwych kontaktów z innymi. Uznanie osobotwórczej siły sportu stało się podstawą wielu programów edukacyjnych. Niektóre z nich poddane zostały badaniom. Wnioski z tych badań potwierdzają ich dydaktyczną i wychowawczą wartość (Czechowski 2001; Nowocień 2001).

Pierre de Coubertin w swoim ogromnym dorobku pisarskim poświęcił najwięcej miejsca pedagogie sportive (termin „edukacja olimpijska” pojawił się w latach 70. XX wieku za sprawą Norberta Müllera - 1975). Nie stworzył on jednak konkretnego systemu wychowawczo-dydaktycznego. Nie przedstawił również jednoznacznej definicji pedagogiki sportowej. W jednym z jego listów znaleźć można słynną wypowiedź, że olimpizm nie jest żadnym systemem, lecz stanem umysłu wywodzącym się z antycznego kultu wysiłku i kultu harmonii. Brak sztywnych ram koncepcji pedagogiki sportowej można uznać za walor, który umożliwia wykorzystanie olimpizmu i jego zasad do rozwiązywania problemów nieustannie rozwijającego się świata, do potrzeb zmieniających się pokoleń i nowych wyzwań (Płoszaj 2014).

Od dziesięcioleci tworzone są rozwiązania metodyczne, za pomocą których dąży się do zrealizowania wartości sportu i olimpizmu w różnych środowiskach, oczekując, że przyniosą one korzyści dla poszczególnych wychowanków i całych grup społecznych. Zainteresowanie tą edukacją wyraźnie wzrasta, tworzone są 
nowe programy, poszerza się także obszar ich implementacji - coraz częściej dostrzega się też ich szerszą rolę wychowawczą, zarówno jako czynnika w kształtowaniu pożądanych postaw i wartości, jak i środka służącego naprawie niekorzystnych zjawisk rozwoju osobowego i społecznego. Tu należy przypomnieć, że ta ostatnia funkcja - naprawcza - pedagogiki sportowej stanowiła pierwotną motywację do jej powołania. Baron Pierre de Coubertin chciał wydobyć z zapaści system szkolnictwa francuskiego.

Analiza zgłaszanych w omawianym obszarze inicjatyw edukacyjnych pozwala wyłonić dwie ich kategorie, takie jak:

1) edukacja olimpijska jako element przygotowań do igrzysk poszczególnych krajów i ich społeczeństw;

2) edukacja olimpijska jako nośny instrument w edukacji młodzieży, z szansami na samorealizację i socjalizację, partnerstwo w interakcjach wychowawczych, pogłębioną refleksję etyczną i rozbudzoną potrzebę własnego doskonalenia - nie tylko w sporcie (Żukowska 1996).

Pierwszą kategorię wypełniają głównie programy przygotowywane w związku ze zbliżającymi się igrzyskami olimpijskimi. Ich autorami są organizacje współdziałające z narodowymi komitetami olimpijskimi - często z krajów będących gospodarzami tych igrzysk (Czechowski 2003). Druga kategoria to programy służące jakościowemu wzmocnieniu edukacji instytucjonalnej - najczęściej szkolnej - skutkujące lepszym rozwojem uczniów i integracją środowiska z wszelkimi jej dobrodziejstwami.

W zakresie obu wymienionych kategorii można znaleźć przykłady działań o różnym zasięgu - od międzynarodowych, przez krajowe, regionalne, instytucjonalne, po indywidualne inicjatywy wychowawców obejmujące klasę szkolną lub zespół sportowy (Nowocień 2001). W podejmowanych przedsięwzięciach wykorzystuje się także różne formy i narzędzia - publikację książek i broszur, organizację imprez, zakładanie stron WWW, przygotowywanie quizów, filmów, przedstawień teatralnych, piosenek, maskotek etc. Można powiedzieć, że jest to różnorodność w jedności celów. Analiza programów edukacji olimpijskiej pozwala wskazać na cztery odmienne typy metodycznych rozwiązań (Naul 2008). Będą to:

1. Metoda oparta na przekazie wiedzy za pomocą publikowanych książek, książeczek, broszur, folderów itp. Inicjatorami są często Akademie Olimpijskie i Kluby Fair Play funkcjonujące przy Narodowych Komitetach Olimpijskich. Zawierają one takie treści, jak historia olimpizmu, poglądy na starożytny i współczesny ruch olimpijski, współczesne terminy, daty, fakty i dyskusje itp. W Europie celują w tym Niemcy, Holendrzy, Słowacy i Czesi. Przykładem stosowania tych metod jest projekt rozwijany w Niemczech „Mach' mit bei der Shülerolympiade".

2. Drugie podejście eksponuje metodę praktycznych działań w postaci organizacji „Dni Olimpijskich”, „Szkół Coubertina”, „Dni Sportu”, obozów młodzieżowych, konkursów fair play itp. W Europie prym wiodą w tym znowu Niemcy, Holendrzy, Czesi i Słowacy. Przykładem może być słowacki projekt „Szkolny Pięciobój dla Sportu, Tolerancji i Fair Play”. 
3. Trzecie podejście wyraża się w doskonaleniu umiejętności motorycznych. Ta metoda jest bliska ideałom olimpijskim, które opisuje Karta Olimpijska: „radość znajdowana w wysiłku”. Celem jest rozwój przez współzawodniczenie, a nie rekord. Chodzi o osiągnięcie samoświadomości, dążenie do sportowej perfekcji, wykształcenie pozytywnych postaw wobec fair play oraz o wzajemny szacunek dla osiągnięć innych osób. Ta metoda stosowana jest $m$.in. w Niemczech.

4. Czwarte podejście wyraża się w kształtowaniu odpowiedniego stylu życia, w którym łączy się olimpijskie pryncypia z doświadczeniem społecznym dzieci i młodzieży, zdobytym w ich codziennym życiu. Metoda ta polega na rozumieniu olimpijskich ideałów jako wyzwania dla osobistych zadań w kontekście całokształtu nabywania przez dzieci i młodzież określonych moralnych zachowań. Przykłady tego podejścia znaleźć można w szczególności w Kanadzie, USA i Australii. Sztandarowym przykładem jest program przygotowany przez Fundację Wychowania Olimpijskiego i Sportowego (FOSE) "Be a Champion in Life".

\section{Odpad szkolny}

Odpad szkolny (school dropout) jest zarówno pojęciem brzydkim i stygmatyzującym, żeby nie powiedzieć obraźliwym, jak i wielowymiarowym. Brzydota i piętnujący charakter tego pojęcia najbardziej są odczuwane przez dotkniętych tym zjawiskiem młodych ludzi - miejmy nadzieję, że w praktyce nieczęsto się oni z nim spotykają.

Z właściwym odpadem szkolnym mamy do czynienia wtedy, gdy uczeń, który uczęszczał do szkoły, przestał to robić, nie kończąc szkoły podstawowej lub gimnazjum - są to ci uczniowie, których „system poświęcił” (Fatyga, Tyszkiewicz, Zieliński 2001, s. 17). Dla naszych rozważań istotny jest także potencjalny odpad szkolny. Jest to kategoria bardzo pojemna i zróżnicowana, a dotyczy uczniów, którzy pozostają w systemie edukacji, ale istnieje duże prawdopodobieństwo, że nie dotrą do poziomów kształcenia wykraczających poza obowiązek szkolny. Z tym zjawiskiem współwystępuje szereg mechanizmów, które stopniowo eliminują ucznia z systemu. Są to m.in.: przenoszenie ucznia do innej „gorszej” szkoły lub klasy, powtarzanie klasy, „przeciąganie na siłę” uczniów przez dany etap i inne (Fatyga, Tyszkiewicz, Zieliński 2001, s. 17). Szczególnie interesującym typem odpadu szkolnego jest odpad szkolny wewnątrzsystemowy - obejmuje on tych uczniów, którzy w sposób trwały zostają zniechęceni do instytucji szkoły, przy czym czynnikiem zniechęcającym mogą tu być zarówno nauczyciele, jak i rówieśnicy, a czasami też inni dorośli, np. rodzice.

Precyzyjne ustalenie przyczyn zaistnienia odpadu szkolnego jest niezwykle trudne, głównie z powodów metodologicznych - wydaje się, że jest to wiarygodne jedynie z zastosowaniem studium indywidualnych przypadków. Mimo wykorzystywania różnych procedur badań autorzy zgadzają się, że zazwyczaj 
współwystępuje wiele powiązanych ze sobą grup czynników wypadnięcia ucznia z systemu edukacji, których swoisty zestaw i układ mają w konkretnym przypadku decydujące znaczenie.

Analiza przyczyn wypadania uczniów z systemu szkolnego ujawnia wiele zmiennych. Na potrzeby tego opracowania posłużymy się opiniami dyrektorów szkół (Fatyga, Tyszkiewicz, Zieliński 2001,s. 99-102), przywołując tylko te zgłaszane przez badanych czynniki powodujące odpad szkolny, które mogą podlegać pełnej lub częściowej neutralizacji pod wpływem zabiegów edukacyjnych.

Z naszego punktu widzenia w pierwszej kolejności trzeba wymienić uwarunkowania sytuacją szkolną - chociaż badani dyrektorzy najczęściej wymieniali przyczyny związane z funkcjonowaniem rodziny. Mamy tu m.in. do czynienia z takimi zjawiskami, jak: trudności w nauce, niepowodzenia szkolne, dzieci mniej zdolne, dzieci z brakami wiedzy, powtarzanie klas, drugoroczność, nieporozumienia na linii nauczyciel-uczeń, niezrozumienie problemów dziecka przez szkołę, strach dzieci przed szkołą. W wypowiedziach dyrektorów szkół najczęściej jako główna przyczyna „złej sytuacji szkolnej” pojawia się „niechęć dzieci do nauki”. Badani wiążą to głównie z przeładowanymi, nieatrakcyjnymi i niezrozumiałymi dla dzieci programami kształcenia. Konsekwencją zetknięcia się z takimi programami jest to, że część uczniów nie radzi sobie z wymaganiami, ma wrażenie przegranej, traci poczucie sensu uczenia się. Niektórzy tacy wychowankowie, wspierani przez rodzinę i szkołę, zdołają utrzymać się w systemie, inni, zazwyczaj pozbawieni wsparcia, powiększają wskaźnik odpadu szkolnego (Fatyga, Tyszkiewicz, Zieliński 2001).

Bardzo często zarówno sukces, jak i porażka ucznia w karierze szkolnej to dzieło wspólne: instytucji (nie tylko szkolnej) oraz rodziny. W grupie przyczyn odpadu szkolnego związanych z sytuacją rodzinną wymienia się m.in.: zaniedbania rodziców, brak pozytywnych wzorców wykształcenia w rodzinie, brak autorytetu rodziców, preferowanie konsumpcyjnego stylu życia w rodzinie oraz, co znamienne (mimo że podejmuje się wiele działań w tym zakresie), brak współpracy rodziców ze szkołą. W opinii dyrektorów szkół istotnym czynnikiem wzmagającym odpad szkolny jest negatywny wpływ środowisk rówieśniczych. Mówi się tu o demoralizacji przez kolegów, podkreśla konflikty z rówieśnikami, przemoc, brak akceptacji przez grupę, szczególnie dzieci drugorocznych.

Jak wynika z cytowanego raportu, gama potencjalnych przyczyn zaistnienia zjawiska odpadu szkolnego jest znacznie szersza niż zasygnalizowane przez nas trzy ich grupy. Z pedagogicznego punktu widzenia wydaje się jednak szczególnie zasadne uznać szkołę, rodzinę i grupę rówieśniczą jako strategicznie najważniejsze środowiska, w których trzeba podejmować działania zaradcze.

\section{Funkcje edukacji olimpijskiej w profilaktyce odpadu szkolnego}

W celu zrealizowania postawionej w tytule pracy tezy postanowiliśmy zadać dwa pytania, które uporządkują nasze poszukiwania: 1) Jaki jest potencjał edukacji olimpijskiej jako czynnika zmniejszającego odpad szkolny? 2) W czym tkwi 
profilaktyczna siła tej koncepcji i jak ją wykorzystać do realizacji takiego zadania? Żeby udzielić odpowiedzi na te pytania, niezbędne jest przedstawienie postulatów pedagogiczno-filozoficznej doktryny olimpijskiej - czyli ujawnienie tego, o jakiego człowieka walczy współczesny olimpizm i na jakiej drodze proponuje go kształtować. Podkreślając współczesność olimpizmu, jednocześnie wskazujemy na jego uniwersalizm edukacyjny. Wynika on zarówno z wartości, jakie upowszechnia, jak i z ciągłego eksperymentowania na polu wychowania. To ostatnie sprawia, że ta koncepcja podlega ciągłej metodycznej aktualizacji. Mając świadomość, że dorobek piśmienniczy w zakresie edukacji olimpijskiej jest bardzo bogaty, a prezentowane w nim poglądy autorów są zróżnicowane, postanowiliśmy oprzeć się na zapisach Karty Olimpijskiej, podstawowego dokumentu ruchu olimpijskiego stanowiącego jego konstytucję - definicja olimpizmu umieszczona na wstępie pracy pochodzi właśnie stamtąd (Karta Olimpijska, 8 grudnia 2014 r.).

Postulat harmonijnego rozwoju wartości ciała woli i umysłu w praktyce oznacza inwestowanie w równym stopniu w rozwój fizyczny, moralny i intelektualny wychowanka. W projekcie edukacyjnym trzeba zapewnić czas i środki pozwalające na odpowiednią stymulację wszystkich tych sfer, dbając przy tym o to, żeby uzyskać osobowość zintegrowaną. Dążyć należy do doboru treści, form i metod, które służyć będą optymalnemu uaktualnieniu potencjału ucznia - na miarę jego sił i warunków społeczno-kulturowych, jakimi dysponuje środowisko - żeby zyskiwał on w procesie edukacyjnym pełną podmiotowość. Błędem byłoby sprowadzenie tej edukacji do postaci zredukowanej wyłącznie do jednego aspektu, np. do sfery cielesnej, skupiając się na rozwoju walorów motorycznych, lub do sfery intelektualnej, opierając się na przekazie wiadomości, czy dbanie przede wszystkim o rozwój moralny przez promowanie zasady fair play. Postulat wszechstronności może być spełniony jedynie jako wyważona całość. Inwestowanie w wszechstronny rozwój ucznia zwiększa szansę na spełnienie jego potencjału i samorealizację. Ma to szczególne znaczenie w przypadku uczniów o mniejszych od przeciętnych zasobach intelektualnych lub o mniejszych możliwościach adaptacyjnych do wymagań stawianych w środowisku szkolnym w zakresie opanowywania wiadomości. Praca nad wartościami ciała powiązana z rozwojem społecznym (moralność) i osobistym (wola) uruchamiają pokłady możliwości wciąż zaniedbywane, ale bardzo ważne i posiadające moc sprawczą.

Postulat radości znajdowanej w wysiłku wyznacza główny cel pracy dydaktyczno-wychowawczej, którym jest osiąganie u uczniów uczucia zadowolenia/ radości z tego, co robią. Chodzi o przesunięcie akcentów z rezultatu, wyniku na drogę, którą uczeń podąża. Sama wędrówka, staranie się, wysiłek mają być dla ucznia źródłem pozytywnych doznań. Akcentujemy tu tak samo wysiłek fizyczny, intelektualny i moralny. Trzeba zwrócić uwagę na samą pracę, nie tylko na efekt, chociaż i on jest ważny. Taka strategia edukacyjna zwiększa szansę na zmniejszenie odpadu szkolnego dlatego, że zwiększa szansę na sukces każdego wychowanka. Uczeń, czerpiąc zadowolenie z tego, co robi i traktując to jako nagrodę, rozwija motywację autoteliczną: poznawanie, ćwiczenie - działanie samo w sobie uzasadnia uczestnictwo i zaangażowanie. W takich warunkach każdy będzie się rozwijał, nawet ten, kogo stać na mniej niż przewidziano w rozporządzeniu. 
Postulat ten zyskuje wartość w świetle badań neurobiologicznych. Wnioski z tych badań wskazują na doniosłą rolę w procesie uczenia się układu limbicznego i znajdującego się w jego ramach ośrodka nagrody - decyzja organizmu o tym, czy dane treści przyjąć, czy odrzucić, uzależniona jest od aktywizacji właśnie tych struktur. Możliwe jest to wtedy, gdy zapewnimy warunki, w których pojawią się poczucie bezpieczeństwa i przyjemność (Żylińska 2013).

Uważamy, że trzeba tu poruszyć jeszcze kwestię samodoskonalenia. Powinno ono być postrzegane nie tylko jako moralny obowiązek pracy nad sobą, ale też jako źródło sukcesu. Sport i olimpizm niosą ze sobą ten postulat bardzo wyraźnie. Wyraża się to m.in. w stwierdzeniu, że najważniejszy jest udział, a nie zwycięstwo. To drugie liczy się najbardziej wtedy, gdy wyraża się w przekraczaniu siebie. Wydaje się, że w edukacji za dużo jest porównywania się z innymi (także do wystandaryzowanych kryteriów osiągnieć), a za mało obserwowania zmian w sobie. W przypadku uczniów, którzy mimo postępów wciąż nie są w stanie tych standardów spełnić, rozwijają się niska samoocena i poczucie klęski, znika też nadzieja, że to się może odmienić.

Postulat łączenia sportu z kulturą. W edukacji olimpijskiej sport odgrywa centralną rolę. Jest nośnikiem wartości i platformą ich urzeczywistniania. Poprzez sport następuje transmisja kulturowa i dokonuje się integracja społeczności szkolnej, można także liczyć na to, że wywoła on motywację uczniów do uczenia się. Znaczny odsetek młodych ludzi wciąż deklaruje zainteresowanie sportem, a jeżeli nie jest to zainteresowanie jego uprawianiem, to przynajmniej chęć oglądania widowisk sportowych.

W pracy wychowawczej trzeba dążyć do łączenia sportu z kulturą, unikać natomiast sytuacji, w których sport sprowadzony jest do agonu/rywalizacji wyizolowanej z kontekstu życia społecznego. W edukacji olimpijskiej zawody sportowe stanowią punkt kulminacyjny, w którym ujawniają się rezultaty wieloaspektowych przygotowań prowadzonych przez wszystkich uczestników. Szkoła to bardzo dobre miejsce na urzeczywistnianie tego postulatu, głównie dlatego, że potrafi uruchomić i stymulować aktywność uczniów w różnych sferach życia. Wynika z tego, że wszyscy powinni dostać rolę w sporcie szkolnym. Każdy uczeń poznaje sportową rywalizację, jest jej widzem, organizatorem, propagatorem, komentatorem, sędzią, działaczem. Pełniąc te rozmaite funkcje, wychowanek poznaje takie dziedziny, jak: ekologia, technika, nauka, sztuka, gospodarka, organizacja, prawo. Rolą nauczycieli/wychowawców jest pokierowanie uczniami tak, żeby zdobyli te wszechstronne doświadczenia zgodnie z celami edukacyjnymi. Jednym z tych celów jest nabycie przez uczniów umiejętności. Uważamy, że kształtowanie umiejętności jest kluczem otwierającym drzwi do rozwoju dla uczniów borykających się z różnymi problemami związanymi z tradycyjnie pojętą nauką szkolną - opanowywaniem wiadomości. W realizacji rozmaitych zadań, jak prowadzenie gazetki sportowej i szkolnego radiowęzła, przygotowywanie się do kibicowania, sędziowanie zawodów sportowych, malowanie plakatów, opracowywanie zestawień wyników, pisanie tekstów hymnów, wierszy, opowiadań, projektowanie nowych konkurencji sportowo-rekreacyjnych, opracowywanie kodeksów, przeprowadzanie licytacji, 
kiermaszów, zbiórek etc., młody człowiek ma okazję zdobyć te kompetencje, które w warunkach ławki szkolnej są niemożliwe do wytworzenia.

Trzeba też podkreślić rolę rodziców w dialogu edukacyjnym. Współpraca szkoły z rodziną w wychowaniu dzieci dzięki projektowi edukacji olimpijskiej może zyskać właściwy zakres. Chodzi o to, żeby trzeci partner procesu wychowania stał się podmiotem świadomym i aktywnym w jego współtworzeniu, a nie tylko opiekunem i inwestorem. Projekty edukacji olimpijskiej są nacelowane na integrację środowiska, włączenie rodziców oraz innych interesariuszy. Dobrym i spektakularnym tego przykładem - na skalę narodową - są programy zrealizowane w Kanadzie i Australii. W tym drugim przypadku szacuje się, że treści edukacji olimpijskiej poprzez dzieci dotarły do 9-12 milionów dorosłych Australijczyków - rodziców (Cathlin 2000; Crawford 1999, 2001).

Postulat dobrego przykładu w edukacji jest doceniany i wykorzystywany od zarania dziejów. Uczenie się od mistrza obecne jest we wszystkich epokach i występujących w nich systemach pedagogicznych. Nic dziwnego, że stało się ono również ważnym elementem koncepcji edukacji olimpijskiej. Wiele wskazuje jednak na to, że współczesna edukacja w coraz mniejszym stopniu jest w stanie ten koncept urzeczywistniać.

Dobry przykład pełni rozmaite funkcje w procesie kształcenia. Może sprawdzić się zarówno w klubie sportowym, szkole, rodzinie, jak i w grupie rówieśniczej. Mówimy tu o zjawisku modelowania: naśladownictwa i identyfikacji. Dzieci i młodzież są niezwykle wrażliwe na tego typu oddziaływanie - niestety również i na takie, które jest wychowawczo wadliwe. Edukację trzeba opierać na dobrych przykładach/wzorcach osobowych. Kto ma odgrywać rolę tych wzorców? W pierwszym rzędzie sami nauczyciele i trenerzy - to oczywiste. Trzeba także szukać ich wśród idoli młodzieży: w sporcie, w sztuce, w życiu społecznym. Szczególnie korzystne wydaje się rozwijanie środowiska wychowawczego tak, żeby samo generowało pozytywne wzorce. Myślę tu o wychowankach, którzy powinni być przygotowywani do obowiązku bycia wzorem zachowania dla innych. Tak właśnie powinna funkcjonować społeczność olimpijska: klasa szkolna, zespół sportowy.

Postulat oparcia się na fundamentalnych i uniwersalnych wartościach. Współczesny olimpizm postuluje realizację takich pryncypiów, jak: pokój, fair play, przyjaźń, braterstwo, wzajemny szacunek, solidarność - lista jest dłuższa, niemniej jednak uznaje się, że wymienione wartości tworzą podstawę aksjologiczną edukacji olimpijskiej. W programach, podejmowanych zarówno w Polsce, jak i na świecie, bardzo chętnie inwestuje się w promocję zasady fair play. Siła edukacyjna fair play wynika z jej uniwersalnego charakteru, a młodzież zgłasza na nią zapotrzebowanie nie tylko w sporcie, ale także w innych sferach ich życia szkolnego i pozaszkolnego. Uważa się, że aspiruje ona do miana systemu etycznego regulującego wybory moralne ludzi. Wprowadzenie do mikrosystemu edukacyjnego zasady fair play może powodować wzrost zdrowia w wymiarze psychospołecznym, które objawia się m.in. dialogiem, poczuciem bezpieczeństwa, spadkiem liczby konfliktów, włączeniem społecznym. Są to warunki sprzyjające budowaniu kultury uczenia się, a także przyczyniające się do ograniczenia negatywnych zjawisk, takich jak: przemoc, wandalizm, zażywanie narkotyków, picie alkoholu czy podejmowanie innych zachowań destrukcyjnych. Z tych względów 
wydaje się zasadne, żeby zasady współżycia zespołów edukacyjnych budować na wartości fair play. Szczególna jest tu rola wychowawców klas, którzy powinni taką pracę podjąć już na pierwszym etapie tworzenia się tych grup. Sprawdzonym narzędziem kształtowania postaw uczniów wobec fair play są warsztaty pedagogiczne (Czechowski, Dąbrowska 2011). Wartościowe są także manifesty sportowe, dekalogi (sportowca, widza, trenera, organizatorów i sędziów), kodeksy etyczne (sportowca, działacza w sporcie, trenera), których podstawą jest fair play. Dokumenty te opisują i wyznaczają kierunki pracy wychowawczej (Czechowski, Żukowska, Żukowski 2011).

$\mathrm{Na}$ temat wychowawczej funkcji fair play wypowiada się wielu autorów. Najznamienitszą przedstawicielką tego grona jest profesor Zofia Żukowska, która w 1994 roku otrzymała za promocję fair play Trofeum Pierre de Coubertin, przyznane przez Międzynarodowy Komitet Fair Play.

Zasada fair play w naturalny sposób postuluje o szacunek wzajemny i solidarność. Uważamy, że akcentowanie tych wartości może mieć duże znaczenie w przeciwdziałaniu niekorzystnym zjawiskom w instytucjach edukacyjnych - dobre wychowanie nie może obejść się bez tych pryncypiów. Jak niezwykle celnie ujął to jeden z największych autorytetów w dziedzinie filozofii olimpijskiej, olimpizm uczy, że: ludzie są równi na starcie; wszyscy powinni podlegać tym samym miarom i kryteriom oceny; ludzie są różni pod względem swych przyrodzonych i nabytych przymiotów, zawsze jednak jest szansa na doskonalenie poprzez pracę nad sobą i wolę zwycięstwa; ludzie są i mogą być uczciwi i szlachetni, ponieważ wiedzą, gdzie przebiega granica między faul a fair; człowiek nigdy nie jest sam - zawsze się z kimś spotyka i zawsze kogoś reprezentuje; człowiek jest wolny, ale zarazem potrafi podporządkować się regułom; żadna rywalizacja nie kończy się definitywnym, absolutnym rankingiem tabelarycznej kolejności, dzisiejszy przegrany może wygrać jutro; choć świat jest skomplikowany, jest on w istocie prosty w swych zasadach; dobro objawia się nie poza realnym światem, lecz w nim samym - w zdrowiu, sprawności, odwadze i radości istnienia, w dążeniu do wszechstronnej doskonałości (Lipiec 1999).

Sport i olimpizm mogą skutecznie wzbogacić program dydaktyczno-wychowawczy każdej instytucji edukacyjnej, a prawdopodobnie także resocjalizacyjnej. Zainteresowanie uczniów sportem może być wykorzystane jako motywacja w nauce. Wartości olimpizmu oraz zjawiska występujące w rzeczywistości olimpijskiej mogą być argumentami w dyskusji nad ważnymi problemami społecznymi. Same zawody sportowe, szkolne, klubowe, a także imprezy rekreacyjne można wykorzystać jako źródło treści dla rozwijania konkretnych umiejętności uczniów. Natomiast „historie olimpijskie” inspirują uczniów do podjęcia działań konstruktywnych i są źródłem inspiracji w dążeniu do lepszego życia (Binder 2000).

Edukacja olimpijska stanowi wszechstronną ofertę wzmacniającą programy dydaktyczno-wychowawcze realizowane przez różne instytucje oświatowe. Jej rola w zmniejszaniu zjawiska odpadu szkolnego może zostać spełniona na drodze: wielostronnej aktywizacji ucznia pozwalającej na lepsze wykorzystanie jego potencjału rozwojowego; integracji zespołów wychowawczych w oparciu o zasadę fair play; motywowania do pracy nad sobą i dla społeczności poprzez radość 
oraz budzenie wiary w lepszą przyszłość i kształtowanie obowiązku dawania dobrego przykładu. To, jak wskazują doświadczenia i wyniki badań, wymaga nie tylko kompetencji pedagogicznych nauczycieli, ale także dużego wysiłku, oddania i poświęcenia wszystkich podmiotów.

\section{Literatura}

Binder D.L., Be a Champion in Life! A Book of Activities for Young People Based on the Joy of Participation and on the Important Messages of the Olympic Idea: an International Teacher's Resource Book for Schools, Foundation of Olympic and Sport Education, Lausanne 2000.

Cathlin J., Olympic Educational Programs in Australia on the Occasion of the Sydney Olympic Game, [w:] Raport on the I.O.A.'s Special Sessions and Seminars, Olimpia 2000.

Crawford S., Sydney's 2000 Olympic Educational Programmes, [w:] Raport on the I.O.A.'s Special Sessions and Seminars, Olimpia 1999.

Crawford S., The Sydney 2000 National Olympic Education Program, [w:] Raport on the I.O.A.'s Special Sessions and Seminars, Olimpia 2001.

Czechowski M., Edukacja olimpijska młodzieży w wybranych krajach, „Wychowanie Fizyczne i Zdrowotne" 2003, nr 12, s. 3-10.

Czechowski M., Promocja wartości fair play w szkołach podstawowych - efekty wychowawcze, [w:] Z. Żukowska, R. Żukowski (red.), Edukacja olimpijska w reformującej się szkole, Estrella, Warszawa 2000, s. 139-148.

Fatyga B., Tyszkiewicz A., Zieliński P., Skala i powody wypadania uczniów z systemu edukacji w Polsce. Raport z badań odpadu szkolnego na terenie 32 gmin, 2001, http://www.isp.org.pl.

International Olympic Committee, Olympic Charter, 2014, http://www.olympic.org.

Lipiec J., Filozofia olimpizmu, PWS Sprint, Warszawa 1999.

Müller N., Olympische Erziehung, [w:] F. Thaller, H. Recla (red.), Signale der Zeit, Hofmann, Schorndorf 1975, s. 138.

Naul R., Olympic Education, Meyer \& Meyer Sport, Aachen 2008.

Nowocień J., Sport i olimpizm w systemie dydaktyczno-wychowawczym współczesnej szkoły, AWF, Studia i Monografie, Warszawa 2001.

Płoszaj K., Funkcjonowanie Klubów Olimpijczyka w szkołach gimnazjalnych, praca doktorska, AWF, Kraków 2014.

Żukowska Z., Wychowawcze funkcje idei fair play w sporcie dzieci i młodzieży, [w:] Z. Żukowska (red.), Fair play - Sport - Edukacja, Estrella, Warszawa 1996, s. 167-169.

Żylińska M., Neurodydaktyka. Nauczanie i uczenie się przyjazne mózgowi, UMK, Toruń 2013. 